\title{
Inducing Molting by Eyestalk Ablation in the Red Swamp Crayfish, Procambarus clarkii from the Egyptian Freshwaters
}

\author{
Mohamed A. Amer*, Awaad A. M. El-Sayed, Khalid A. Al-Damhougy, Samir A. Zaahkouk \\ Faculty of Science, Al-Azhar University, Cairo, Egypt
}

Email address:

naser12_7@yahoo.com (M. A. Amer)

To cite this article:

Mohamed A. Amer, Awaad A. M. El-Sayed, Khalid A. Al-Damhougy, Samir A. Zaahkouk. Inducing Molting by Eyestalk Ablation in the Red Swamp Crayfish, Procambarus clarkii from the Egyptian Freshwaters. American Journal of Life Sciences. Special Issue: New Horizons in Basic and Applied Zoological Research. Vol. 3, No. 6-1, 2015, pp. 69-75. doi: 10.11648/j.ajls.s.2015030601.20

\begin{abstract}
Eyestalk ablation was used for inducing molting in the freshwater crayfish, Procambarus clarkii at the laboratory conditions. The results exhibited that, both of unilateral and bilateral eyestalk removal accelerated molting rate than in nonablated or intact individuals of this species. The use of unilateral eyestalk removal has low effect, induced molting at the $6^{\text {th }}$ week and reached $100 \%$ at the end of the $16^{\text {th }}$ week, compared with starting molting at the $8^{\text {th }}$ week for control, which did not exceed than $40 \%$ for molted individuals at the end of experiment, with $20 \%$ mortality for each. On contrast, the bilateral ablation has high effects and induced molting rapidly at the first and second weeks for the two experiments. It was associated with high mortality rates, averaged $28.33 \%$ for ablated individuals of the two experiments, increased gradually to $51.67 \%$ and $80.0 \%$ for individuals of the premolt stages, which showed signs of molting but were unable to complete molting cycle and died at the end of the last week of each experiment. Repeating molting was recorded for only one bilateral ablated animal after 11 days, but no molting was noticed for control group, with mortality of $20 \%$.The percentages of increments in body dimensions included body length, carapace length, chelae length and total body weight were calculated. Most ratios of increments, except only total body weight, were high in ablated males than ablated females, as well as clearly higher in normal molted males and females than ablated ones, but declined sharply to $3.30 \pm 2.91 \%$ in total body weight for bilateral ablated males.
\end{abstract}

Keywords: Crayfish, Molting, Eyestalk Ablation, Ecdysone, Bilateral

\section{Introduction}

The red swap crayfish, Procambarus clarkii belongs to family Cambaridae. The individuals of this species live in many freshwater bodies of the south-central U.S.A., particularly Louisiana [1]. During the last decades, the occurrence of this species extended to other countries including Europe, Australia and China [2], and introduced into the Egyptian freshwaters via a private fish farm during early 1980's [3\&4]. During the last decade of the twentieth century, this species became one of the faunal components of the Egyptian freshwaters habitats and provides about 4.6 tons of the annual yield [5] and represents a new natural protein resource with high nutritive value. At the present time, this species became requested among freshwater fisheries, and consumes by many Egyptian peoples as cheap food, with high protein, instead of the other high expensive marine shrimps and lobsters $[4,6,7]$.

As it well known, the growth of crustaceans depends mainly on molting which is a biological and physiological tool accompanied with increasing size, weight and length and controlled by environmental and endocrine hormones [8]. However, there are several factors that affect molting processes, among which eyestalk ablation. Removal of eyestalk induces molting by direct affecting the endocrine system of the crayfish [1\&9]. The first direct evidence for hormonal control of molt was given by [10], where they found that removal of both eyestalks from the crayfish Orconectes virilis caused an acceleration of molting, while injection of the contents of eyestalks into the body of an eyestalkless animal delayed molting activity. These investigations were supported by many workers comprised [1, $9,11,12,13,14,15,16,17,18,19,20]$.

The relations between growth and molt intervals in the 
eyestalkless crayfish, Procambarus clarkii were also documented by several studies. Successive molting was studied by [15\&21]. While the effects of bilateral eyestalk removal on molting of juveniles Procambarus clarkii was treated by [22]. Similar studies were also carried out on shrimps and prawns $[18,19,23]$.

The objective of this study to accelerating molting by using eyestalk removal and evaluate increments rates in both ablated and normal individuals of the introduced freshwater crayfish, Procambarus clarkii within the Egyptian freshwater drainage canals and Nile River to use for increasing size and improvement production.

\section{Materials and Methods}

\subsection{Animal Collection}

The specimens of Procambarus clarkii were collected alive from River Nile tributaries at Al-Kanater Al- Khairiya (Qalyoubia Governorate, Egypt), during June, July and August 2010. They were transported to the laboratory in the Faculty of Science Al-Azhar University, Naser City, Cairo. Sex was determined, and each animal was weighed to the nearest $0.01 \mathrm{~g}$ after blotting excess water with absorbent tissues using an electric balance with an accuracy of $0.01 \mathrm{~g}$. All body length, carapace length and right chela length were measured by a Vernier caliper with an accuracy of $0.01 \mathrm{~mm}$. All specimens were mature and varied from 6.5 to $10.5 \mathrm{~cm}$ in standard length and from 9.1 to $48.25 \mathrm{~g}$ in the total body weight.

The collected crayfishes were divided temporary into groups and kept for two weeks in water tanks containing fresh water $(50 \mathrm{~L})$, aerated with air pumps at room ambient temperature, with oxygen concentration up to $7-8 \mathrm{mg} / \mathrm{L}$, and $\mathrm{pH}$ varied from 7.8 to 8.0 , and fed on commercial pellets, frozen fish meat and squids. Tanks water was changed at the end of each week, with aerated water under the same conditions. Molting stages were determined according to [8\&24].

\subsection{Eyestalk Ablation}

A total of 100 mature specimens (52males and 48 females all were in the inter molt stages), were used for eyestalk ablation during this study. The surgical removal was used for both unilateral and bilateral eyestalk ablation according to $[18,19,23]$, where the eyestalk extirpation of the X-organ sinus gland complex was successful ablated. To reduce mortality to the minimum level, the sterile surgical blades were used for eyestalk removal. During ablation, the specimens were held in pre-cooled water in order to reduce heartbeat, loss of haemolymph and to control bleeding. All changes in carapace characters denoting to molting signs, number of molted individuals, repeating molting and mortality rates for the two experiments were recorded and calculated.

\subsubsection{Unilateral Ablation Experiment}

For unilateral eyestalk ablation, 20 specimens were used, 5 control and 15 individuals were ablated by removing one eyestalk. The ablated individuals were divided into three groups ( 5 specimens in each) in aquaria of $30 \times 40 \times 60 \mathrm{~cm}$, and compared with 5 eyestakless or intact individuals. This experiment extended for 16 weeks, during the period from the $28^{\text {th }}$ of August to the $24^{\text {th }}$ of November 2010, under the prevailing ambient temperature and natural photoperiod, with water temperature ranged between $23^{\circ}$ and $25^{\circ} \mathrm{C}$, conductivity varied from 0.5 to $0.56 \mathrm{~ms}$, and dissolved oxygen ranged between 7.6 to $8 \mathrm{mg} / \mathrm{L}$.

\subsubsection{Bilateral Ablation Experiments}

For bilateral eyestalk ablation, 60 specimens were bilaterally ablated, and 20 specimens for controls these were divided into two experiments as following:

- The first experiment was experienced during the period from the $10^{\text {th }}$ to $31^{\text {st }} \mathrm{July,} 2010$. Total of 40 individuals thirty (30) bilateral ablated specimens were divided into three groups (10 in each), and compared with control (10 normal specimens). Both of the treated and control groups were put in aquaria of $30 \times 40 \times 100 \mathrm{~cm}$, with water temperature varied between $28^{\circ}$ and $29^{\circ} \mathrm{C}$, conductivity $0.4-0.6 \mathrm{~ms}$, dissolved oxygen $7-7.8 \mathrm{mg} / \mathrm{L}$, at the natural photo period.

- The second experiment was carried out from $7^{\text {th }}$ to $21^{\text {st }}$ August 2010 on 40 animals (30 treated and 10 controls) under the same prevailing laboratory conditions.

\subsection{Molt Increments}

The ratios of increments in body dimensions (total length, standard length, carapace length and chelae length, as well as total body weight) were calculated by the difference between the values of these dimensions before and after molting process according to the following formula:

$$
\text { Increments }(\%)=\frac{L_{2}-L_{1}}{L_{1}} * 100
$$

Where $\mathrm{L}_{1}=$ length or weight before molting, and $\mathrm{L}_{2}=$ length or weight after molting.

Statistical analyses by using (MINITAB 14) program, student T- test was used to evaluate the significant differences between values of these dimensions.

\section{Results}

\subsection{Eyestalk Ablation}

Results in tables (1\&2) show the pronounced effects for eyestalk ablation on the onset and duration of molting and mortality rates in the freshwater crayfish Procambarus clarkii. The hypotheses that tested in these experiments was accelerating molting by eyestalk ablation to reduce intermolt period and fasting growth. The effects of these treatments differ significantly according to the type of eyestalk ablation. 


\subsubsection{Unilateral Eyestalk Ablation}

Results in table (1)exhibits the onset of molting and mortality rates for the unilateral eyestalk ablated individuals compared with a control group in an experiment carried out for 16 weeks. These results revealed that, only three ablated individuals were died during the first 3 weeks (one in each), represented $20.0 \%$ (mortality) of total. The remaining 12 individuals (amounted $80 \%$ of the total), were molted by the end of the last $16^{\text {th }}$ week. First appearance for molting was recorded at the $6^{\text {th }}$ week, where two individuals were molted (13.33\%). Molting continued through the following successive 5 weeks (from $7^{\text {th }}$ to the $11^{\text {th }}$ weeks), amounting $91.67 \%$ from all molted individuals, and showed a high ratio at the $9^{\text {th }}$ week $(20.0 \%)$. The last animal had been molted at the last $\left(16^{\text {th }}\right)$ week, giving $80 \%$ of the all eyestalk ablated individuals and $100 \%$ of the all live treated animals.

For control group, only two animals molted at the $8^{\text {th }}$ and $13^{\text {th }}$ weeks, representing $40 \%$ of all specimens, with low mortality rate $(20 \%)$, represented by death of only one animal during the $8^{\text {th }}$ week (Table 1).

\subsubsection{Bilateral Eyestalk Ablation}

For bilateral ablation, the results of the first and second experiments are shown in Table (2). These results exhibit that, the effect of bilateral eyestalk ablation on molting is more effective, and induced molting at the $1^{\text {st }}$ and $2^{\text {nd }}$ weeks for the second and first experiments respectively, but was accompanied by high mortality. For the first experiment, seven specimens molted during the $2^{\text {nd }}$ week, amounting $23.33 \%$ from the whole individuals and stayed with this ratio till the end of the $3^{\text {rd }}$ week. Out of the molted animals, only one repeated molting rapidly at the $3^{\text {rd }}$ week after 11 days from the first one represented $3.33 \%$ of the total number of individuals and $14.28 \%$ of the molted ones.

Mortality rates for these experiments were high, particularly at the first week. It was represented by death of 7 individuals $(23.33 \%)$, but declined to $4(13.33 \%)$ at the $2^{\text {nd }}$ week. The remaining 12 individuals ( $40 \%$ of the total) reached the late premolt stage $\left(D_{4}\right)$, and were very close to ecdysis. They were characterized by the appearance of molting suture between the first abdominal segment and hind edge of the cephalothorax (carapace), and have large gastroliths. However, these specimens were in a bad healthy case, very exhausted, move slowly, and were unable to complete molting. They died at the end of the $3^{\text {rd }}$ week, increased mortality into $76.66 \%$ (Table,2).

On the other hand, no evidence for molting was noticed for control group, but 3 animals died during the first and second weeks, represented $30.0 \%$ of the whole individuals (Table 2).

The same pattern was noticed for the second experiment (Table, 2). The results showed that, molting rate was very low, started at the first week with $3.33 \%$, increased to $13.33 \%$ at the $2^{\text {nd }}$ week, and amounted $16.66 \%$ from the whole individuals. Mortality rate was high and represented by death of 6 animals without referring any signs of molting, from which 4 were died during the first week, followed by two at the $2^{\text {nd }}$ week, amounted $20.0 \%$ from all. In spite of the other 19 animals $(63.33 \%)$ reached the premolt stage $\left(\mathrm{D}_{4}\right)$, and were closely to ecdysis, but were unable to molt, and died at the end of the $2^{\text {nd }}$ week, increased mortality to $83.33 \%$.

For control group, no signs for molting were recorded, and mortality rate was very low (10\%), represented by only death of one animal at the first week (Table 2).

\subsection{Percentage of Increments}

\subsubsection{Increments in Unilateral Eyestalk Ablated Animals}

The increments in body dimensions for unilateral ablated animals are presented in Table (3) and Figure (1). These data exhibit that, the maximum increments were $16.52 \pm$ 14.29 and $13.15 \pm 7.71 \%$ in total body weight for both ablated males and females, respectively, while the minimum ratios were $6.66 \pm 2.91$ and $6.21 \pm 3.29 \%$ in standard length, for the same sexes, respectively. However, the ratios of increments in male's total length, standard length, and chelae length averaged $8.79 \pm 3.70,6.66 \pm 2.91$, and $8.07 \pm 6.02 \%$, respectively. These ratios are being slightly higher in males than females, and were statistically significant for chelae length only (T-test $=1.235, \mathrm{P}<0.05$ ). On contrast, the average percentages of increments in females' total body weight was higher in females than males, with slightly increase in females' carapace lengths but without significant difference with males (T-test $=0.72, \mathrm{P}>$ $0.05)$.

In comparison with the molted non-ablated or intact males, all increments in unilateral ablated males were lower than normal ones without significant statistically ( $\mathrm{T}$ test $=0.53, \mathrm{P}>0.05$ ). Only exception was recorded in the total body weight, which was slightly higher in ablated males $(13.15 \pm 7.71 \%)$ than that in normal males $(12.11 \pm 6.32 \%)$. The reverse was recorded in the increments of the total length and carapace length in ablated females, which were slightly higher than normal females. While as, the ratio of increments in the standard length was very close between the two groups. However, the increments in total body weight of unilateral ablated females were significantly higher in ablated females than normal females, and the reverse was noticed for increments in chelae length (Table, 3, Figure, 2), which was significantly higher in non-ablated molted females than ablated animals ( $\mathrm{T}$ test $=2.12, \mathrm{P}<0.05$ ).

\subsubsection{Increments in Bilateral Eyestalk Ablation}

All bilateral ablated animals were males (Table, 3 ). The percentage of increments was varied from $3.30 \pm 2.91 \%$ in body weight to $10.01 \pm 6.74$ in total body length. All increments in body weight, standard length, carapace length and chelae length were lower in bilateral ablated males than normal molted ones (Table, 3), but the increments in the total length was the exception, being slightly higher in ablated males $(10.01 \pm 6.74 \%)$ than normal non-ablated ones $(9.62 \pm 5.09 \%)$. The sharp decline in the increments of total body weight to $3.30 \pm 2.91 \%$ represents the lowest 
value for increments during this work. Morever, the increments in repeated molting animal were relativelly low compared with control and other single molted one.

\section{Discussion}

The present knowledge about molting suggests that, molting is hormonally controlled by at least two hormones. These are: 1) - The molt inhibiting hormone: which is a peptide [25], is formed in the X-organ - a discrete group of neurosecretory cells bodies located in the eyestalk, transported in their axons to the sinus gland, stored there and released by the sinus gland into the blood to inhibit of the Yorgan molting hormone during the intact period of the intermolt [24]. 2) - The molting hormone: secretes by Yorgan, which is an endocrine gland, situated just posterior of the esophagus [8, 24, 26, 27]. The crustacean molting hormone has identified as 20-hydroxyecdysterone, a molecule similar to insect ecdysone, except it has an $\mathrm{OH}-$ group at the 20 position [28]. Although the roles of the Yorgan and its secretion ecdysone are well established, there is controversy, or lack of information, about other aspects of the control of molting, particularly the role of cephalic gland situated in the antennal segment of $O$. lomosus as mentioned by [24\&28].

Several studies and documents revealed that, removal of eyestalk or eyestalk ablation had a significant effect on molting in crustaceans, particularly decapods $[8,17,18,19$, 20, 29]. Removal of eyestalk or the Y- organ inhibitor during the intermolt results the release of molting hormone and a series of morphological and histological changes are begun which culminate in ecdysis [24\&27], and followed by the onset of a molting cycle, characterized firstly by the gastroliths formation [13\&24].

In $P$. clarkii, removal of eyestalk promotes molting and increases the growth increments over several molts despite the increased mortality in these animals[13\&24].The molting periods for ablated individuals, declined from 151.5 days in control to 39.1 days in ablated ones during five successive molting as mentioned by [24].

During the present study, a remarkable inducing for molting was recorded by both unilateral and bilateral eyestalk ablation. It was also found that, the effect of bilateral ablation was greatly higher than unilateral ones. The results showed that, molting processes were initiating rapidly at the first and second weeks for the bilateral ablated individuals, but delayed to the $6^{\text {th }}$ week for unilateral ones. However, the rapid initiating molting at the bilateral individuals was accompanied by high mortality rates in comparison with that of the unilateral treated individuals, and all bilateral ablated individuals were died at the end of the second or third weeks. Moreover, repeating molting was recorded for the bilateral individual after 11 days from the first one.

Therefore, the present results are in agreement with the previous findings, particularly, those mentioned by [13\&24] on crayfish $P$. clarkii from USA, and [20] on the narrowclawed crayfish, Astacus leptodactylus from Iran. They reported that, there was a high mortality rate in bilateral eyestalk- ablated and a high survival rate in unilateral ablated animals, however, the present results denoted to shortest interval molting period than mentioned by [13\&24] on the same species ( $P$. clarkii) from USA. Also, the same results were reported by [30] on Homarus americanus, [33] on Astacus astacus, [31] on Orconectes virilis, [32] on Astacus astacus, [17] on Procambarus clarkii, [19] on Metapenaeus lankesteri and M. dobsoni, and [30] on Metapenaeus monoceros. All these studies confirm that, eyestalk ablation is shortening molting periods and initiating molting cycle, but bilateral ablation is more effective and associated with high mortality. [29] reported a rapid increase of ecdysteroid and a significant shorter molting interval in destalked Macrobrachium rosenbergii prawns in comparison with intact ones.

[18]Found that, removal of eyestalk leads to weight increase and osmolality decrease of haemolymph. But [34] stated that unilateral eyestalk ablation has been employed to induce ovarian maturation and spawning with varying success in many crustaceans. It can also be used to shorten the molt interval and to stimulate gonad development in decapods as mentioned by [18]. Although the bilateral eyestalk ablation shortens the molt interval, it can also cause additional mortality, because ablation simultaneously removes the four ganglia in each eyestalk, a considerable portion of central nervous system [17\&33]. Therefore, ablation induced hormonal imbalance or stress, which often results in high mortality[16\&18]. The same results were recorded during this study by death of premolt individuals which were very exhausting and could not complete molting, increasing mortality rates. The death of these individuals may be due to hormonal imbalance or stress as mentioned by [16].

The present data showed that, there are observed significantly increments in body dimensions for unilateral ablated individuals particularly for males than females except body weight, which may be attributed to sexual dimorphism. However, the lower increments in most body dimensions of bilateral ablated males than normal or non ablated ones may be attributed to the effects of ablation as results of hormonal imbalance or stress as mentioned by [16] or stopping feeding under the stress of these effects. Therefore, these results are in contrast with that mentioned by [27]which indicated increasing the frequency of molting which accelerates the size increase of body dimensions beyond that in normal animals by eyestalk ablation. This may be due to abnormal increase in water uptake since there is no increase in total nitrogen as mentioned by [27].

\section{Conclusion}

The present study provides an idea about increasing body dimensions slightly beyond the hypothetical size and improvement production of this species by controlling molting cycle and mortality at local mass production; but further studies on the effects of the environmental factors are still needed. 


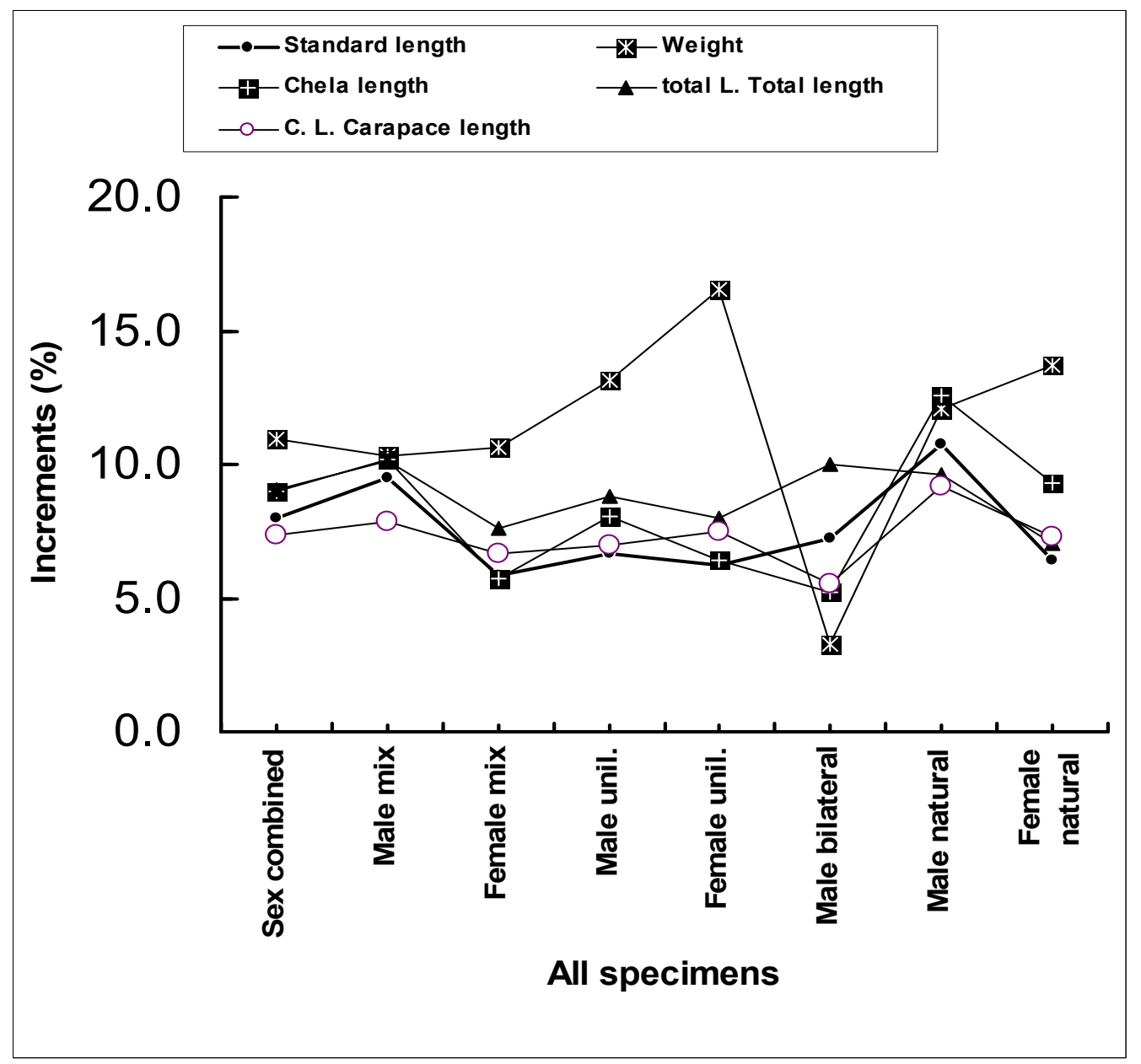

(mix: ablated and non-ablated, unil: unilateral ablation)

Figure (1). Percentage of increments in molted specimens (bilateral and unilateral eyestalk ablated individuals) and non-ablated (naturally molted individuals) in both of males, females and sex combined.

Table (1). Ratios of molting and mortality rates for unilateral eyestalk ablated and control individuals of P. clarkii from the Egyptian freshwaters.

\begin{tabular}{|c|c|c|c|c|c|c|c|c|}
\hline \multirow{3}{*}{ Weeks } & \multicolumn{4}{|c|}{ Unilateral ablated specimens } & \multicolumn{4}{|c|}{ Control } \\
\hline & \multicolumn{2}{|c|}{ Molting rate } & \multicolumn{2}{|c|}{ Mortality rate } & \multicolumn{2}{|c|}{ Molting rate } & \multicolumn{2}{|c|}{ Mortality rate } \\
\hline & No. & $\%$ & No. & $\%$ & No. & $\%$ & No. & $\%$ \\
\hline $1^{\text {st }}$ & - & - & 1 & 6.67 & - & - & - & - \\
\hline $2^{\text {nd }}$ & - & - & 1 & 6.67 & - & - & - & - \\
\hline $3^{\text {rd }}$ & - & - & 1 & 6.67 & - & - & - & - \\
\hline $4^{\text {th }}$ & - & - & - & - & - & - & - & - \\
\hline $5^{\text {th }}$ & - & - & - & - & - & - & - & - \\
\hline $6^{\text {th }}$ & 2 & 13.13 & - & - & - & - & - & - \\
\hline $7^{\text {th }}$ & 2 & 13.13 & - & - & - & - & - & - \\
\hline $8^{\text {th }}$ & 1 & 6.67 & - & - & 1 & 20 & 1 & 20 \\
\hline $9^{\text {th }}$ & 3 & 20.0 & - & - & - & - & - & - \\
\hline $10^{\text {th }}$ & 2 & 13.13 & - & - & - & - & - & - \\
\hline $11^{\text {th }}$ & 1 & 6.67 & - & - & - & - & - & - \\
\hline $12^{\text {th }}$ & - & - & - & - & - & - & - & - \\
\hline $13^{\text {th }}$ & - & - & - & - & 1 & 20 & & \\
\hline $14^{\text {th }}$ & - & - & - & - & - & - & - & - \\
\hline $15^{\text {th }}$ & - & - & - & - & - & - & - & - \\
\hline $16^{\text {th }}$ & 1 & 6.67 & - & - & - & - & - & - \\
\hline Total & 12 & 80.0 & 3 & 20.0 & 2 & 40.0 & 1 & 20.0 \\
\hline
\end{tabular}


Mohamed A. Amer et al:: Inducing Molting by Eyestalk Ablation in the Red Swamp Crayfish,

Procambarus clarkii from the Egyptian Freshwaters

Table (2). Molting and mortality rates for bilateral eyestalk ablated and control individuals of P. clarkii from the Egyptian freshwater.

\begin{tabular}{|c|c|c|c|c|c|c|c|c|c|c|c|}
\hline \multirow{3}{*}{\multicolumn{2}{|c|}{ Experiments }} & \multicolumn{6}{|c|}{ Bilateral ablated specimens } & \multicolumn{4}{|c|}{ Control } \\
\hline & & \multicolumn{2}{|c|}{ Mortality rate } & \multicolumn{2}{|c|}{ Molting rate } & \multicolumn{2}{|c|}{ Exhausted Premolt } & \multicolumn{2}{|c|}{ Mortality rate } & \multicolumn{2}{|c|}{ Molting rate } \\
\hline & & No. & $\%$ & No. & $\%$ & No. & $\%$ & No. & $\%$ & No. & $\%$ \\
\hline \multirow{4}{*}{$\begin{array}{l}\text { Exp. (1) } \\
\text { (weeks) }\end{array}$} & $1^{\text {st }}$ & 7 & 23.23 & - & - & - & - & 2 & 20 & - & - \\
\hline & $2^{\text {nd }}$ & 4 & 13.33 & 7 & 23.33 & 12 & 40.00 & 1 & 10 & - & - \\
\hline & $3^{\text {rd }}$ & - & - & $1^{(*)}$ & 3.33 & $"$ & $"$ & - & - & - & - \\
\hline & Total & 11 & 36.66 & 7 & 23.33 & 12 & 40.00 & 3 & 30 & - & - \\
\hline \multirow{3}{*}{$\begin{array}{l}\text { Exp. (2) } \\
\text { (weeks) }\end{array}$} & $1^{\text {st }}$ & 4 & 13.33 & 1 & 3.33 & - & - & 1 & 10 & - & - \\
\hline & $2^{\text {nd }}$ & 2 & 6.67 & 5 & 13.33 & 19 & 63.33 & - & - & - & - \\
\hline & Total & 6 & 20.0 & 6 & 16.66 & 19 & 63.33 & 1 & 10 & - & - \\
\hline \multicolumn{2}{|c|}{ Average \pm SD } & 17 & 28.33 & 13 & 20.0 & 31 & 51.67 & 4 & 20.0 & 0 & 0 \\
\hline
\end{tabular}

(* Denotes to repeating molting, Exp.= experiment).

Table (3). Percentages of increments in naturally and ablated molted individuals (average $\pm S D$ ).

\begin{tabular}{|c|c|c|c|c|c|c|c|c|c|c|c|c|}
\hline \multirow{2}{*}{\multicolumn{3}{|c|}{ Parameters }} & \multicolumn{2}{|c|}{ Standard length } & \multicolumn{2}{|c|}{ Body weight } & \multicolumn{2}{|c|}{ Chelae length } & \multicolumn{2}{|c|}{ Total length } & \multicolumn{2}{|c|}{ Carapace length } \\
\hline & & & (cm) & $\%$ & (gm) & $\%$ & $(\mathrm{~cm})$ & $\%$ & $(\mathrm{~cm})$ & $\%$ & $(\mathrm{~cm})$ & $\%$ \\
\hline \multirow{4}{*}{ 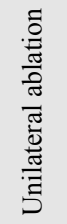 } & \multirow[t]{2}{*}{$\hat{0}$} & $\begin{array}{l}\text { Average } \\
\pm \mathrm{SD}\end{array}$ & $0.55 \pm 0.22$ & $6.66 \pm 2.91$ & $3.07 \pm 1.57$ & $13.15 \pm 7.71$ & $0.28 \pm 0.25$ & $8.07 \pm 6.02$ & $0.81 \pm 0.30$ & $8.79 \pm 3.70$ & $0.33 \pm 0.15$ & $6.95 \pm 3.61$ \\
\hline & & Range & $0.6-0.7$ & $7.8-8.2$ & $2.9-5.6$ & $15.9-17.8$ & $0.16-0.89$ & $4.6-21.3$ & $0.9-1.1$ & $9.3-13.1$ & $0.24-0.25$ & $4.8-5.8$ \\
\hline & \multirow[t]{2}{*}{ q } & $\begin{array}{l}\text { Average } \\
\pm \mathrm{SD}\end{array}$ & $0.52 \pm 0.25$ & $6.21 \pm 3.29$ & $4.14 \pm 3.97$ & $16.52 \pm 14.29$ & $0.20 \pm 0.07$ & $6.43 \pm 3.15$ & $0.75 \pm 0.32$ & $7.99 \pm 3.83$ & $0.35 \pm 0.17$ & $7.50 \pm 4.09$ \\
\hline & & Range & $0.2-0.9$ & $2.1-11.3$ & $1.47-4.5$ & $4.57-24.3$ & $0.13-0.27$ & $3.24-11.2$ & $0.3-1.2$ & $2.91-13.3$ & $0.19-0.59$ & $3.7-13.2$ \\
\hline \multirow{4}{*}{ 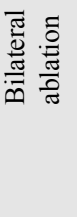 } & \multirow{2}{*}{$\hat{\jmath}$} & $\begin{array}{l}\text { Average } \\
\pm \mathrm{SD}\end{array}$ & $0.56 \pm 0.51$ & $7.21 \pm 7.04$ & $1.24 \pm 0.77$ & $3.30 \pm 2.91$ & $0.22 \pm 0.16$ & $5.25 \pm 3.76$ & $0.92 \pm 0.58$ & $10.01 \pm 6.74$ & $0.26 \pm 0.15$ & $5.53 \pm 3.33$ \\
\hline & & Range & $0.1-1.3$ & $1.1-18.1$ & $0.1-1.8$ & $0.3-6$ & $0.03-0.35$ & $0.7-9.12$ & $0.4-1.6$ & $4.1-18.8$ & $0.2-0.5$ & $1.59-10$ \\
\hline & \multirow[t]{2}{*}{$\hat{\sigma}$} & $\begin{array}{l}\text { Average } \\
\pm \mathrm{SD}\end{array}$ & $0.80 \pm 0.36$ & $10.76 \pm 5.45$ & $2.51 \pm 1.28$ & $12.11 \pm 6.32$ & $0.42 \pm 0.14$ & $12.56 \pm 5.08$ & $0.85 \pm 0.44$ & $9.62 \pm 5.09$ & $0.41 \pm 0.22$ & $9.15 \pm 5.22$ \\
\hline & & Range & $0.3-1.5$ & $3.9-21.1$ & $1.1-4.68$ & $2.2-21.9$ & $0.16-0.58$ & $4.6-19.8$ & $0.4-1.8$ & $4.4-20.9$ & $0.14-0.85$ & $3.1-20$ \\
\hline \multirow{2}{*}{\multicolumn{2}{|c|}{ 胥 }} & $\begin{array}{l}\text { Average } \\
\pm \mathrm{SD}\end{array}$ & $0.52 \pm 0.31$ & $6.42 \pm 3.97$ & $2.18 \pm 0.95$ & $13.72 \pm 11.52$ & $0.25 \pm 0.04$ & $9.31 \pm 4.30$ & $0.66 \pm 0.34$ & $7.05 \pm 3.71$ & $0.33 \pm 0.18$ & $7.29 \pm 4.05$ \\
\hline & & Range & $0.2-0.9$ & $2.2-11.3$ & $1.2-3.4$ & $4.2-32$ & $0.2-0.23$ & 4.4-11.9 & $0.4-1.2$ & $4.1-13.3$ & $0.1-0.6$ & $2-13.2$ \\
\hline
\end{tabular}

[7] Raafat, H. A.: Biological and physiological studies on the freshwater crayfish, Procambarus clarkii, Ph. D. Thesis, Department of Zoology, Girls College for Arts, Science and Education, Ain Shams University, 2006, 267 pp.

\section{References}

[1] Huner, J.V. and Lindqvist, O. V.: Special problems in freshwater crayfish egg production. In: Crustacean egg production, (eds. A. Wenner and A. Kuris), 1995, pp. 235-264.

[2] Huner, J.V. Moody, M. and Thure, R.: Cultivation of freshwater crayfish aquaculture in North America, Europe and Eustralia. Families Astacidae, Cambridae and Parastacidae. Haworth press, New York, 1993.

[3] Ibrahim, A.M.; Khalil, M.T. and Mubarak, M.F.: On the feeding behavior of the Exotic crayfish, P. clarkia in Egypt and its prospects in the bicontrol of local vector snails. . J, Union Arab Biol., Cairo. Vol.4,No. A, 1995, pp 321-340.

[4] Ibrahim, A.M. and Khalil, M.T.: The red swamp crayfish in Egypt. (A fast spreading freshwater invasive crustacean), Egypt. Centre of Research \& Studies of Protectorates, Ain Shams Unv.Vol.1,2009, pp: 153.

[5] Ibrahim, A. M.; Emam W. M.; Beltagy S. M.; Tharwat, A. A. and Mubarak F. M.: On some factor affecting molting of the crayfish Procambarus clarkii from the River Nile Egypt. $J$. Environ. Sci., vol.1, No.1, 2000, pp23-45.

[6] Mona, M.H.; Geasa, N.M. Sh.; Sharshar, Kh. M. and Morsy, E.M.: Chemical composition of freshwater crayfish (Procambarus clarkii) and its nutritive value. Egypt. J. Aquat. Biol. And Fish.,vol.4, No.1,1999, pp 19 - 34.

[8] Warner, G. F.: The Biology of crabs. Elek Science, London, 1977, pp119-140.

[9] Chang, E. S.: Physiological and biochemical changes during the molt cycle in decapod crustaceans. J. Exp. Mar. Biol. \& Ecol., vol. 193, 1995, 1-14.

[10] Brown, F. A. and Cunningham, O.: Influence of sinus gland of crustaceans in normal ability and ecdysis. Biol. Bull. Woods Hole, vol. 77, 1939, pp 104-114.

[11] Carlisle, D. B.: Moulting hormones in Leander (Crustacea: decapoda). J. mar. Biol. Assoc., U. K. vol. 32, 1953 a, pp289296.

[12] Adiyodi, K. J. and Adiyodi, R. J.: Endocrine control of reproduction in decapod Crustacea, Biol. Rev., vol. 45, 1970, pp 121-165.

[13] Nakatani, I. and Otsu, T.: The relationship between growth and molt interval in the eyestalkless crayfish, P. clarkia. Comp. Biochem. Physiol., vol. 68, No. A, 1979, pp549-553.

[14] Jegla, T. C.; Ruland C.; Kegel G.; and Keller R. (): The role of the Y-organ and cephalic gland in ecdysteroid production and the control of molting in the crayfish, Orconectes limosus, USA, Comp Physiol., vol. 152, 1983, pp91-95. 
[15] Naya, Y. and Ikeda, M.: Comprehensive survey of endogenous regulators of crustacean moulting. Pure \& Appl. Cham.,Vol. 65, No.6, 1993, pp1265-1270.

[16] Chen S.; Huner, J. V. and Malone, R. F.: Moulting and mortality of red swamp and White River crawfish subjected to eyestalk ablation: Preliminary study for commercial soft-shell crawfish production. Journal of the world Aquaculture Socity, vol. 24, 1993, pp48- 57.

[17] Chen S., Wu, J. and Malone R. F. (): Effects of temperature on mean molt interval, molting and mortality of red swamp crawfish' (Procambarus clarkii), Aquaculture, vol. 131,1995, pp. 205-217.

[18] Venkitraman, P.R.; Jayalakshmy, K.V.; Balasubramanian, T.; Nair, M. and Nair, K.K.C.: Effect of eyestalk ablation on the growth and moulting of penaeid prawns Metapenaeus dobsoni(de Man), Indian J. Exp. Biol., vol.42, 2004, pp. 403412 .

[19] Venkitraman, P. R.; Jayalakshmy, K. V.; Balasubramanian, T.: Effect of eyestalk ablation on molting and growth in penaeid prawns Metapenaeus monoceros. Indian J. Fish., vol. 57, No. 2, 2010, pp. 25-32.

[20] Hesni, M. A.; Shabanipour, N.; Atabati, A. and Bitaraf, A. (): Influence of eyestalk ablation and temperature on molting and mortality of Narrow-clawed crayfish (Astacus leptodactylus).Turkish Journal of Fisheries and Aquatic Sciences, vol. 8, 2008, pp. 219-223.

[21] Bittnerand, G. D. and Kopanda R.(): Factors influencing molting in the crayfish Procambarus clarkii. J. of Experimental Zoology; Vol. 186, issue"1,1995, pp. 7 - 16.

[22] Ibrahim, A. M.; Emam W. M.; Mubarak F. M.; Beltagy S. M. and Tharwat, A. A.: On the reproductive biology of the crayfish Procambarus clarkii from the River Nile Egypt. $J$. Egypt, Acad., Environ. develop., vol. 7, No. 1, 2006, pp. 145171.

[23] Sainz-Hernándeza, J. C.; Racotta, I. S.; Dumas, S. and Hernández - López, J.: Effect of unilateral and bilateral eyestalk ablation in Litopenaeus vannamei male and female on several metabolic and immunologic variables, Elsevier, Aquaculture, vol. 283(1-4),2008, pp. 188-193.
[24] Lowery, R.S.: Growth, molting and reproduction. In: Freshwater Crayfish, Biology, Management and Exploitation (Holdich, D.M. and Lowery, R.S., Eds.). Croom Helm Press, London, 1988, pp. 83-113.

[25] Ranga Rao, K.: Isolation and partial characterization of the moult -inhibiting hormone of the crustacean eyestalk. Experientia, vol. 21, 1965, pp. 593-594.

[26] Passano, L. M.: Low temperature blocking of moulting in Uca pugnax, Biol. Bull., vol. 188, 1960, pp. 129-136.

[27] Yamaoka, L. H. and Scheer, B. T.: Chapter: 11: Chemistry of growth and development in crustaceans. In: Chemical Zoology; Academic Press, London, Vol. (A) 1970, pp. 321338 .

[28] Willing, A. and Keller, R.: Moulting hormone content, cuticle growth and gastrolith growth in the molt cycle of the crayfish Orconectes limosus. J. comp. Physiol., vol. 86,1973, pp. $377-$ 388 .

[29] Okumura, T. and Katsumi, A.: Effect of bilateral eyestalk ablation on moulting and ovarian development in the giant freshwater prawn, Macrobarchium rosenbergii, J. Fresh. Sci., vol. 67, 2001, pp. 11- 25.

[30] Aiken, D. E., Waddy, S. S., Castell, J. D. and Covey, J. F.: Effect of sex, temperature, diet and holding conditions on growth of intact and eyestalk ablated lobsters (Homarus americanus). Division Fish Oceanography, 1977, pp. 7: 13.

[31] Aiken, D. E., Waddy, S. S.: Molting and growth in crayfish: a review .Can. Tech. Rep. Fish. Aquat. Sci., 587, 1987, $34 \mathrm{pp}$.Effect of sex, temperature, diet and holding conditions on growth of intact and eyestalk ablated lobsters (Homarus americanus). Division Fish Oceanography, 7: 13.

[32] Gydemon, R. and Westin, L.: Investigation on eyestalk ablation in Astacus astacus. J. Aquat. Product., vol. 2, 1988, pp. 155-171.

[33] Huner, J.V. and Lindqvist, O. V.: Effect of temperature and diet on reproductively active male noble crawfish (Astacus astacus) subjected to bilateral eyestalk ablation. J. of the world aquaculture Soc., vol. 15, 1994, pp. 138-141.

[34] Zaib Un Nisa Ahmed, M.: Natural and inducing spawning of Pakistan Penaeid shrimps in the laboratory, Aquaculture, vol. 33, No. 2, 2001, pp. 125-130. 